Aleksy Kwilinski,

Ph.D., The London Academy of Science and Business, England

Kazimierz Pajak,

Dr.Sc., Professor, Institute for International Cooperation Development, Poland

Oleksandr Halachenko,

Ph.D., Associate professor, Vinnytsya Institute of PJSC «Higher Educational Institutions «MAUP», Ukraine

Svitlana Vasylchak,

Dr.Sc., Professor, Lviv State University of Internal Affairs, Ukraine

Yaroslav Pushak,

Dr.Sc., Professor, Lviv State University of Internal Affairs, Ukraine

Paulina Kuzior,

Silesian University of Technology, Poland

\title{
MARKETING TOOLS FOR IMPROVING ENTERPRISE PERFORMANCE IN THE CONTEXT OF SOCIAL AND ECONOMIC SECURITY OF THE STATE: INNOVATIVE APPROACHES TO ASSESSMENT
}

Abstract. The paper summarizes the arguments for a scientific discussion on solving the problem of improving the efficiency of the enterprise in the context of social and economic security of the state. The main purpose of the study is to evaluate the effectiveness of the enterprise and on its basis to identify innovative measures and methods, effective marketing tools to improve it. The systematization of literary sources and scientific approaches showed that, based on a comprehensive assessment of the activity of the enterprise, there remained several unsolved problems regarding the improvement of the social and economic security of the state. The urgency of solving this scientific problem lies in ensuring social and economic security that is an extremely important problem in the current conditions of the country's development. Methodical tools of the study are such methods as a logical generalization, systematic, comparison, mathematical calculations, graphical, method of expert assessments. The study period is 2014-2018. The object of the study is the sanatorium and resort enterprise since the social and economic security of the state on the micro-level is formed based on the activity of such enterprises. The research of the identified problem in the paper is carried out in the following logical sequence. The significance of the activity of enterprises as an integral part in shaping the country's economy in market conditions is outlined. The important role of domestic enterprises in ensuring the employment of the country's population, the formation of social relations and support of social stability, the social and economic security of the state at the micro-level is noted. The problems of provision of enterprises economic development as a component of socioeconomic security of the state in need of research are highlighted. The list of risks, which domestic enterprises are subjected to in daily activity, is described. It is noted that the economic development of enterprises is one of the components of securing social and economic security of the country at the micro-level. In this context, the theoretical basis for the formation of economic security of enterprises is investigated based on the evaluation of the efficiency of the activity on the example of sanatorium and resort institutions. An evaluation of the efficiency of activity of sanatorium-resort enterprises from the standpoint of the economic entity efficiency based on the calculation of integral index and directly by consumers with the help of an expert method is conducted. Based on the estimation of the integral coefficient of efficiency of the sanatorium and resort services provision on the example of the past five years, the unevenness of the fluctuations of the main economic indicators of activity, reduction of the coefficient of financial and economic activity efficiency has been proved. Based on surveys of consumers, the average mark of the effectiveness for the provided sanatorium services was set at 3.7 points, which at the five-point scale proves the need for improving the activity of sanatorium and resort facilities under present conditions and developing special events using effective instruments stimulating the development of such enterprises. To significantly improve the efficiency of sanatorium and resort enterprises and the impact on the improvement of social and economic security in the country, a set of actions and marketing tools based on the innovative technologies at the enterprise, regional and state level. The results of the conducted research can be used by sanatorium and resort establishments in practical activity and public authorities, local self-government bodies at the level of regions

Cite as: Kwilinski, A., Pajak, K., Halachenko, O., Vasylchak, S., Pushak, Y., \& Kuzior, P. (2019). Marketing Tools for Improving Enterprise Performance in the Context of Social and Economic Security of the State: Innovative Approaches to Assessment. Marketing and Management of Innovations, 4, 172-181. http://doi.org/10.21272/mmi.2019.4-14 
A. Kwilinski, K. Pajak, O. Halachenko, S. Vasylchak, Y. Pushak \& P. Kuzior. Marketing Tools for Improving Enterprise Performance in the Context of Social and Economic Security of the State: Innovative Approaches to Assessment

and territorial communities in developing projects of development of territories and taking measures to ensure social and economic security in the country.

Keywords: economic security, efficiency, measures, innovative approaches, marketing tools, assessment, sanatorium and resort establishments, social and economic security.

Introduction. The activity of the enterprises and their development is an important component of the economy of our country in market conditions. Domestic enterprises play an important role in ensuring employment of the country's population, forming public relations and supporting social stability. The functioning of enterprises in any country is extremely important for the social and economic importance because the provision of social and economic security at the micro level depends on the level of their development. It is important to note that economic security and stability are the greatest challenges in the crisis world (Wysokinska-Senkus and Senkus, 2015; Wysokinska-Senkus and Raczkowski, 2013). The «Circle of Sustainability» physics provides a relatively simple view to the stability of a specific city, urban settlement or region. The circled figure is divided into four areas: ecology, economics, politics and culture (James, 2015). The basis of a sustainable economy is effective enterprises activity. The effective activity of enterprises forms not only economic safety but also the social one. After all, security has two dimensions: negative, threats and risks, and positive - opportunities, income and social security (Navidnia, 2009). Economic security and the Welfare Index are also combined by American scholars who argue that problems such as employment, income, poverty, education, health, crime and violence are interconnected (Mason et al., 2013). Forming the processes of targeted improvement in the activity of the enterprises in the light of new challenges, the strategy aims to provide components of social and economic security and analysis of risk elements (Wysokinska-Senkus and Senkus, 2013). Experience has shown that the importance and impact on the development of enterprises in economically developed countries are to provide innovative effects based on the introduction of innovations. Innovation factor is considered as the dominant factor of stable development considering restrictions in the internal and external business environment (Dudin et al., 2014). The dynamics of socio-economic development and the quality of its reflection at the macro and micro level is determined by innovation itself (Dudin et al., 2013). Innovation development and social stability of the economic system of the region are also interconnected (Pakulina, 2015).

Literature Review. An analysis of the world trends in the development of economies, the scientific and technological process of interaction of world integration proves the need to highlight the key drivers of economic security (Reshetova and Krutik, 2011). An assessment of the security of the country is impossible without identifying the retrospective development of economic entities. Researches were conducted in this direction by several other foreign scientists. It has been proved that the change in the level of economic security in the countries shows a reduction in their economic development during the years of the economic crisis (Grigoreva and Fesina, 2013; Grigoreva and Garifova, 2015). Among the domestic scientists, who studied the problems of the enterprises' development in the context of providing the economic security of the state, were: T. Vasyltsiv and S. Hrynkevych (2015), L. Kurhuzenkova (2016), O. Didchenko (2012), S. Vasylchak and O. Halachenko (2016). The conducted researches have been devoted mainly to the problems of providing economic security as subjects of management as well as the state, which is a component of social and economic security. Despite the number of studies conducted and the publication of their results, the problems of securing the economic development of enterprises as a forming component of the social and economic security of the state remain unresolved. Therefore, the purpose and subject of this paper is a study of the impact of enterprise effectiveness on the social and economic security of the state based on the assessment as one of the innovative approaches.

The importance of evaluating the efficiency and functioning of the system of economic security (SES) for enterprises was highlighted by S. Kavun, D. Caleta, M. Vrsec, R. Brumnik, where conceptual principles and model basis are based on some real indicators of a functioning enterprise (Kavun et al., 2013). The 
works of Amosha et al., 2016; Bezchasnyi, 2018; Bezchasnyi et al., 2018; Bilan et al., 2019; Boiko et al., 2019; Dalevska et al., 2019; Dzwigol and Dzwigol-Barosz, 2018; Dzwigol et al., 2019; Kaminska, 2018; Kunze, 2012; Kuzior et al., 2019; Kwilinski, 2018a; 2018b; 2019; Kwilinski et al., 2019; Lyulyov et al., 2018; Lyulyov and Shvindina, 2017; Lyulyov and Pimonenko, 2017; Pajak et al., 2016; 2017; Savchenko et al., 2019; Tarasova, 2018; Tkachenko et al., 2019a; 2019b; 2019c; 2019d; Vasylieva et al., 2018; Zaloznova and Trushkina, 2017; and other, also had a particular impact on the innovative approaches to assessment of marketing tools for improving enterprise performance in the context of social and economic security of the state.

Methodology and research methods. Methodical tools of the study are such methods as a logical generalization, systematic, comparison, mathematical calculations, graphical, method of expert assessments. For the development of domestic enterprises, regardless of the organizational form and direction of specialization, they are exposed to various risks and threats in their daily activity. They can include manufacturing, technological, environmental, financial, personnel and others. All possible risks and threats to a greater or lesser extent have a negative impact on economic performance and the result on the economy, social situation and its social and economic security. After all, the economic development of the enterprises is one of the components of securing the social and economic security of the country. The functioning of business entities, the formation of relations between them and other structures, with international partners determine most risks and dangers for the national economic system. In the context of this, we support the views of researchers T. Vasyltsiv and S. Hrynkevych concerning the fact that solution of problems and ensuring the economic security of entrepreneurship as a component of the national social and economic security in countries that are just developing their economies, which include and Ukraine, deserves special attention (Vasyltsiv and Hrynkevych, 2015).

Exploring the chronology of the development of the term "social and economic security», it is worthwhile to note that it was singled out as a separate direction of economic security at the end of the past and the beginning of the present century. Taking into account the interpretation of domestic scientists (Kurhuzenkova, 2016; Didchenko, 2012), it is possible to distinguish the following features of the essence of the economic security of enterprise: the absence of threats and dangers, effective activity that ensure the economic development of the enterprise and its competitiveness, prevention of the negative impact of external and internal factors. As has already been mentioned above, the key to the economic security of the enterprise is its economic status. An assessment of the efficiency of functioning of the enterprise and its impact on the country's social and economic security was studied on the example of sanatorium and resort institutions of Vinnytsia region. In this context, the effectiveness of the sanatorium and resort enterprises has been determined from the position of:

1) efficiency of the business entity, in this case, the sanatorium and resort institution;

2) consumers directly.

The efficiency of providing sanatorium and resort services for each separate sanatorium and resort institution was determined based on the integral indicator by the formula:

$$
K_{\text {efprov }}=\frac{\mathrm{K}_{\text {ef fin }}+\mathrm{K}_{\text {ef grant }}+\mathrm{K}_{\text {ef bp }}}{3}
$$

where $K_{\text {ef prov. }}$ - coefficient of efficiency for the provision of sanatorium and health resorts services; $K_{\text {effin. }}$ - coefficient of efficiency for financial and economic activity of the business subject; $K_{\text {ef grant. }}$ coefficient of efficiency for granting medicinal, preventive and rehabilitation services; $\mathrm{K}_{\mathrm{ef} b \mathrm{~b} \text {. }}$-coefficient of efficiency of using bed places in sanatorium and resort establishment.

Results. The results of calculating the integral coefficient of efficiency for providing sanatorium and resort services on the example of the enterprise (to reduce the risk of enterprise's image of the company, the authors have beheaded the name of the company. 
According to the results of research and titles, please contact the authors) for the last five years taking into account the initial data of statistical and financial reporting (Accounting and financial reporting of the enterprise for 2014-2018.) prove uneven fluctuations of the main economic indicators where the amount of profits is reduced and the cost of the provided sanatorium and resort services is increasing. As a result, the coefficient of efficiency for financial and economic activity of the sanatorium-resort establishment has decreased from 0,201 to 0,039 (Figure 1).

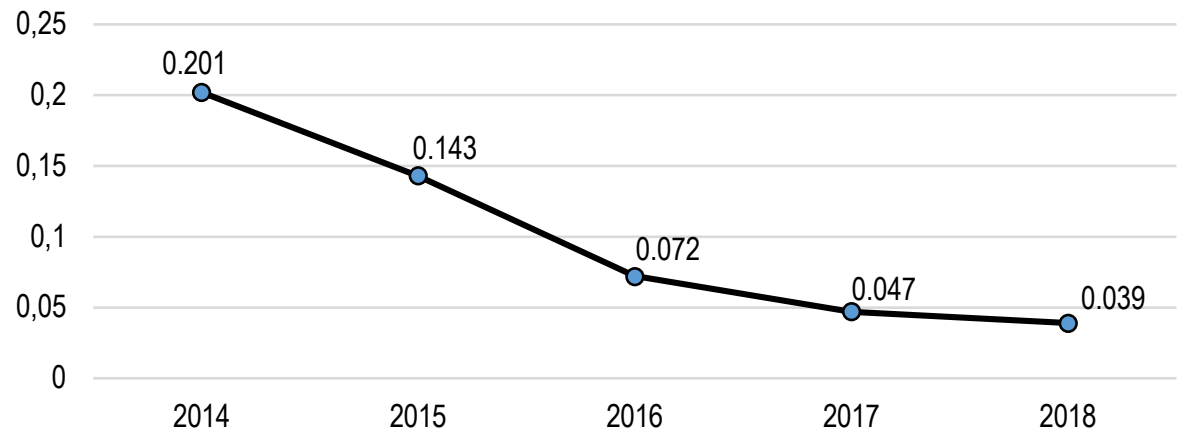

Figure 1. The coefficient of efficiency of financial and economic activity of the sanatorium and resort establishment

Source: Calculated by the author based on Accounting and financial reporting of the enterprise for 2014-2018.

The number of clients gravely reduced in the years 2014-2015 which is associated with political and, as derivative, economic processes happened in our country. However, the number of patients of the given health-improving institution, starting from 2016, is growing a bit of what is associated with an increase of the sick in rehabilitation profile. During the period of study, the number of recovered with stable results of treatment and rehabilitation increases which positively affects the improvement of the coefficient for the efficiency of treatment and prevention and rehabilitation services provision (from 0,801 in 2014 to 0,875 in 2018) (Figure 2).

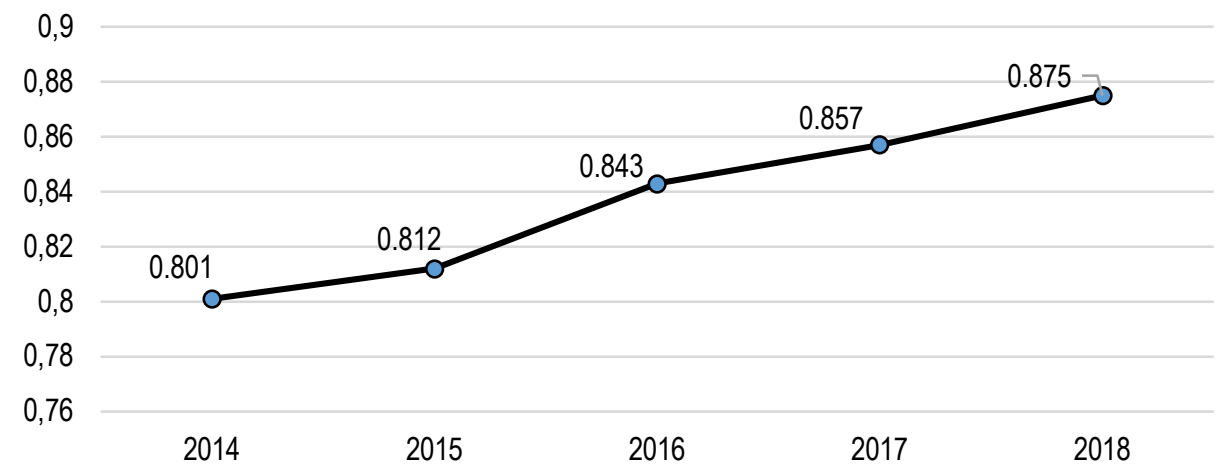

Figure 2. The coefficient of effectiveness of providing medicinal, preventive and rehabilitation services

Source: Calculated by the author based on Accounting and financial reporting of the enterprise for 2014-2018. 
The average duration term of recovery is reduced. The coefficient of efficiency for bed places use varies from 0,809 in 2014 to 0,926 in 2018 . The lowest value for the years $2014-2015$ is 0,809 and 0,862 respectively (Figure 3 ).

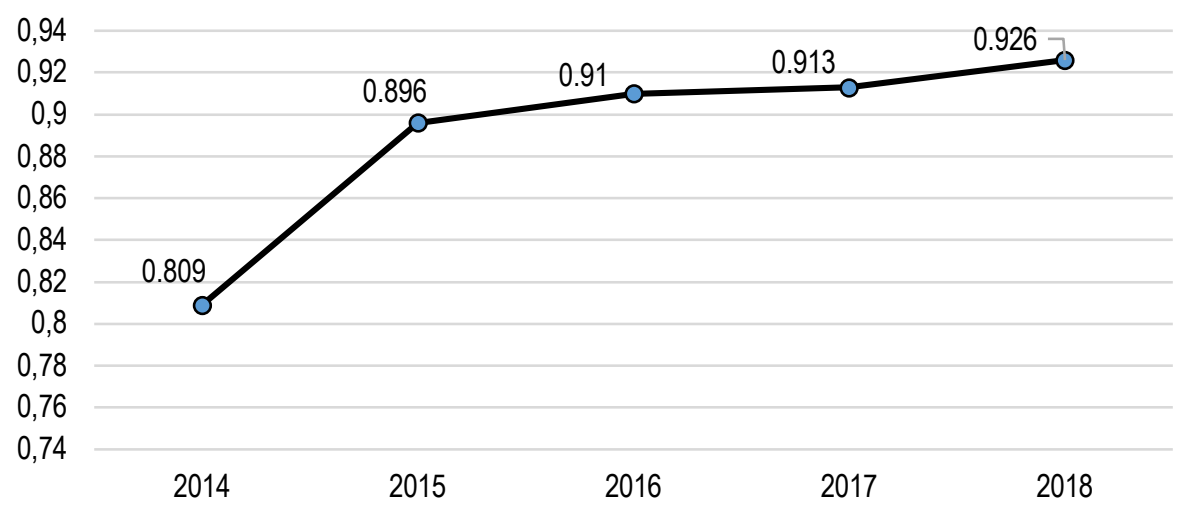

Figure. 3. The coefficient of efficiency of the bed places use in the sanatorium and resort institution

Source: Calculated by the author based on Accounting and financial reporting of the enterprise for 2014-2018.

The performed calculations show that despite the improvement of the coefficient of efficiency for medicinal, preventive and rehabilitation services provision and the coefficient of the efficiency for the use of bed places in the sanatorium and resort establishments, the coefficient of efficiency for providing sanatorium and resort services at the enterprise for the period of 2014-2018 decreased into 0,061 compared with the base 2014 (Figure 4).

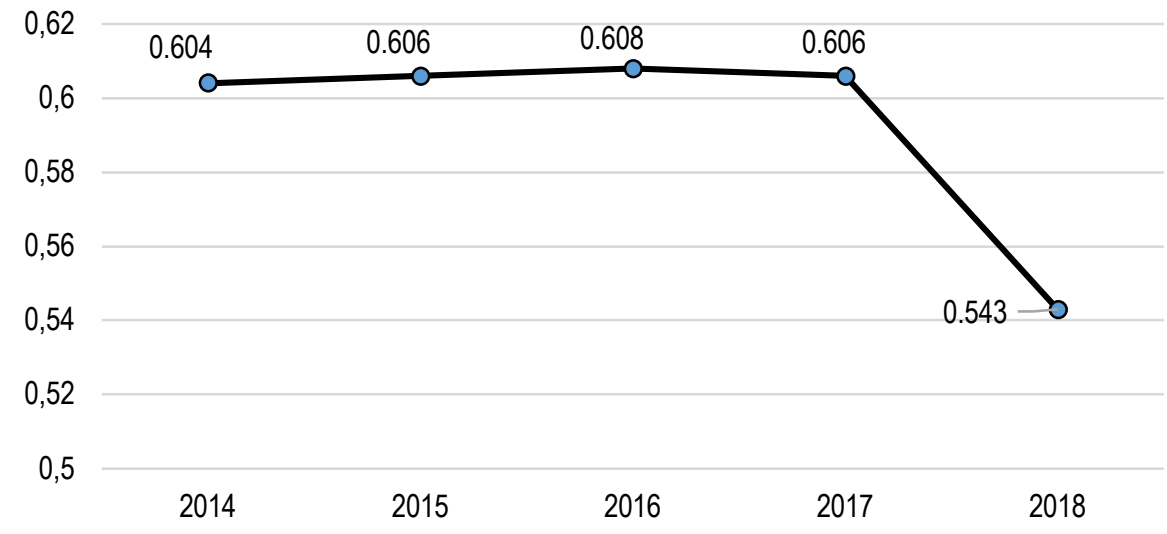

Figure 4. The coefficient of efficiency of sanatorium and resort services providing

Source: Calculated by the author based on Accounting and financial reporting of the enterprise for 2014-2018. 
A. Kwilinski, K. Pajak, O. Halachenko, S. Vasylchak, Y. Pushak \& P. Kuzior. Marketing Tools for Improving Enterprise Performance in the Context of Social and Economic Security of the State: Innovative Approaches to Assessment

Shown in the table testifies the deterioration of the performance of health-improving establishment functioning that needs the development of the special measures and use of effective tools for stimulation of sanatorium and resort services development (Table 1).

Table 1. Assessment of the effectiveness of the sanatorium and resort services providing on the example of the enterprise interface

\begin{tabular}{|c|c|c|c|c|c|c|}
\hline Indicator & Formula for calculation & 2014 & 2015 & 2016 & 2017 & 2018 \\
\hline $\begin{array}{c}\text { 1. Coefficient of efficiency } \\
\text { for the financial and } \\
\text { business activity of } \\
\text { sanatorium and resort } \\
\text { establishment }\end{array}$ & Profit/cost of services sold & 0.201 & 0.143 & 0.072 & 0.047 & 0.039 \\
\hline $\begin{array}{c}\text { 2. Coefficient of } \\
\text { effectiveness for provision } \\
\text { of medicinal, preventive } \\
\text { and rehabilitation services } \\
\begin{array}{c}\text { Number of healed people } \\
\text { with sustainable results of } \\
\text { treatment and rehabilitation } \\
\text { / Number of consumers of } \\
\text { sanatorium and resort } \\
\text { services in a health- } \\
\text { improving establishment }\end{array}\end{array}$ & 0.801 & 0.812 & 0.843 & 0.87 & 0.875 \\
\hline $\begin{array}{c}\text { 3. Coefficient of efficiency } \\
\text { for use of bed places in } \\
\text { the sanatorium and resort } \\
\text { institution }\end{array}$ & $\begin{array}{c}\text { Number of healed people in } \\
\text { recalculation onto the bed- } \\
\text { days spent in the } \\
\text { sanatorium and resort } \\
\text { institution / Number of bed- } \\
\text { days based on the number } \\
\text { of beds in the sanatorium } \\
\text { and resort institution }\end{array}$ & 0.809 & 0.862 & 0.910 & 0.913 & 0.926 \\
\hline $\begin{array}{c}\text { 4. Coefficient of efficiency } \\
\text { for providing sanatorium } \\
\text { and resort services }\end{array}$ & $\begin{array}{c}\text { Calculated by formula 1 } \\
\text { Cand }\end{array}$ & 0.604 & 0.606 & 0.608 & 0,606 & 0.543 \\
\hline
\end{tabular}

Source: Calculated by the author based on Accounting and financial reporting of the enterprise for 2014-2018.

Assessment of the relative efficiency and quality of sanatorium and resort services provision from the position of the consumer also has important meaning where interests of the user himself act as important questions in the evaluation. The efficiency of providing services by sanatorium and resort institutions is reached if consumer spending his/her time and money received services that improved his/her health condition, physical and spiritual possibilities (Vasylchak and Halachenko, 2016). Since the quantitative assessment of the effectiveness of sanatorium and resort services through the subjective assessment of the consumer is difficult, the study used an expert method where the insiders were clients of the healthimproving institution (Halachenko, 2016; Vasylchak et al., 2017). Based on the consumer survey on the five-point scale, we summarized the overall results of all questionnaires that were distributed among the visitors of the health-improving institutions while and after treatment was completed and returned to the reception. Medium mark of the efficiency for the sanatorium and resort services provided was calculated by the consumers' responses totality using the formula:

$$
Q_{\text {cep }}=\frac{\sum_{i=1}^{m} \sum_{j=1}^{n} S_{i j}}{m \times n}
$$

where $\mathrm{O}_{\text {cep }}$ - the average rating of the results of consumers poll; $\mathrm{S}_{\mathrm{ij}}$ - the sum of points got from the $\mathrm{i}^{\text {th }}$ consumer for the $j^{\text {th }}$ question in the questionnaire, score; $m$-the number of sanatorium and resort services users who were involved in monitoring, units; $n$ - the number of questions that were included into the 
questionnaire, units. By the results of the calculations, the medium mark of the efficiency of the provided sanatorium and resort services in the whole population of respondents was 3,7 points, which proves the need to improve the activity of the sanatorium and resort establishments in the present day that could ultimately affect the improvement of social and economic security in the country.

Conclusions. Based on the study it can be considered that according to economic assessments, the effectiveness of sanatorium and resort enterprises is not high and requires the adoption of innovative measures and methods, effective marketing tools for improvement. Among them, it is possible to offer a set of actions at the level of the enterprise itself, at the level of the region and the state. At the level of the health-improving establishments, it is expedient to improve the quality of the sanatorium and resort services, expand their spectrum and optimization of cost to the level of the given parameters, production of sanatorium and resort services based on the latest technologies and medical innovations, optimization of costs and terms of medicinal, preventive and rehabilitation services provision to balance the solvency of demand and supply; the use of marketing tools such as branding, trends of social media marketing, system-reflexive marketing which will improve the predictability of business processes, promotion of sanatorium, awareness of health-improving establishment on the service market, its brand and will enhance its image. At the level of the region, in the context of decentralization, it is expedient to develop the territories of resort development projects, implement global experience of financial support for small and medium enterprises based on innovative technologies in the sphere of resort activity, take innovative measures to improve the infrastructure of resorts, increase their investment attractiveness.

The adoption of legislative and regulatory acts by public authorities to improve the sanatorium and resort enterprises activity, the introduction of budget support mechanism and the mechanism of financial compensation of the cost of sanatorium and resort vouchers by social fund insurance, organization of the system of state information support including at the international level, should be the main approaches at the macro level. Offered measures, methods and marketing tools based on innovative technologies will significantly increase the efficiency of sanatorium and resort enterprises, which will affect the improvement of social and economic security in the country. The authors suggest that the results of the study can be used by sanatorium and resort enterprises in practice and by public authorities, local government bodies at the level of regions and territorial communities when developing territorial development projects and taking measures to ensure social and economic security in the country.

Author Contributions: Conceptualization, A. K., K. P., O. H.,S. V., and Y. P.; methodology, A. K., O. H., S. V., and Y. P.; software, A. K., O. H., S. V., Y. P., and P. K.; validation, A. K., K. P., O. H., S. V., and Y. P.; formal analysis, A. K., O. H., S. V., Y. P., and P. K.; investigation, A. K., O. H., S. V., and Y. P; resources, A. K., O. H., S. V., and Y. P.; data curation, A. K., O. H., S. V., and Y. P.; writing-original draft preparation, A. K., K. P., O. H., S. V., Y. P., and P. K.; writing-review and editing, A. K., O. H., S. V., and Y. P.; visualization, A. K., O. H., S. V., Y. P., and P. K.; project administration, A. K., O. H., S. V., and Y. P., and P. K.; funding acquisition, A. K., K. P., O. H., S. V., Y. P., and P. K.

\section{References}

Amosha, O., Kharazishvili, Y., Liashenko, V., \& Kvilinskyi, O. (2016). Economic security of sustainable development of the regions (based on the example of the Donetsk region). In K. Pająk (Ed.), Gospodarka niskoemisyjna $i$ jej wplywa na rozwój województwa wielkopolskiego [Low-carbon economy and its impact on the development of the Wielkopolska voivodship] (pp. 1934). Warszawa: Wydawnictwo Naukowe PWN.

Bezchasnyi, O. (2018). Reflexive coordination of communications in the construction of models for the development of an industrial enterprise. Virtual Economics, 1(1), 66-83. https://doi.org/10.34021/ve.2018.01.01(5) 
A. Kwilinski, K. Pajak, O. Halachenko, S. Vasylchak, Y. Pushak \& P. Kuzior. Marketing Tools for Improving Enterprise Performance in the Context of Social and Economic Security of the State: Innovative Approaches to Assessment

Bezchasnyi O., Khobta V., Pushak Ya., Kotkalova-Litvin I., \& Dorovska I. (2018). Modeling of control stability of communication channels in development management. Financial and Credit Activity: Problems of Theory and Practice, 4(27), 282-295. https://doi.org/10.18371/fcaptp.v4i27.154116

Bilan, Y., Lyeonov, S., Luylyov, O., Pimonenko T. (2019). Brand management and macroeconomic stability of the country. Polish Journal of Management Studies, 19(2), 61-74. https://doi.org/10.17512/pjms.2019.19.2.05

Boiko, V., Kwilinski, A., Misiuk, M., \& Boiko, L. (2019). Competitive advantages of wholesale markets of agricultural products as a type of entrepreneurial activity: the experience of Ukraine and Poland. Economic Annals-XXI, 175(1-2), 68-72. https://doi.org/10.21003/ea.V175-12

Dalevska, N., Khobta, V., Kwilinski, A., \& Kravchenko, S. (2019). A model for estimating social and economic indicators of sustainable development. Entrepreneurship and Sustainability Issues, 6(4), 1839-1860. https://doi.org/10.9770/jesi.2019.6.4(21)

Didchenko, O.l., (2012). Pidkhody do vyznachennia poniattia «ekonomichna bezpeka pidpryiemstva» ta rol derzhavy v yii formuvanni [Approaches to defining the concept of «economic security of the enterprise» and the role of the state in its formation] Theoretical and practical aspects of economics and intellectual property, 1(1), 186-190. https://doi.org/10.31498/22256407.1.2012.6108 [in Ukrainian].

Dudin, M. N., Ljasnikov, N. V., Pankov, S. V., \& Sepiashvili, E. N. (2013). Innovative Foresight as the Method for Management of Strategic Sustainable Development of the Business Structures. World Applied Sciences Journal, 26(8), 1086-1089.

Dudin, M.N., Lyasnikov, N.V., Veselovsky, M.Y., Sekerin, V.D., \& Aleksakhina, V.G. (2014). The problem of forecasting and modelling of the innovative development of social-economic systems and structures. Life Science Journal, 11(8). Retrieved from http://www.lifesciencesite.com/lsj/life1108/077_24896life110814_549_552.pdf

Dzwigol, H., \& Dzwigol-Barosz, M. (2018). Scientific Research Methodology in Management Sciences. Financial and Credit Activity: Problems of Theory and Practice, 2(25), 424-437. https://doi.org/10.18371/fcaptp.v2i25.136508

Dzwigol H., Aleinikova O., Umanska Y., Shmygol N., \& Pushak Ya. (2019). An entrepreneurship model of assessing the investment attractiveness of regions. Journal of Entrepreneurship Education, 22(1), 1-7. Retrived from https://www.abacademies.org/articles/An-entrepreneurship-model-for-assessing-the-investment-1528-2651-22-S1-339.pdf

Grigoreva, E., \& Fesina, E. (2013). Economic Security as a Condition of Institutional Support of Economy Modernization. World Applied Sciences Journal, 31(5), 940-948.

Grigoreva, E., \& Garifova, L. (2015). The Economic Security of the State: The Institutional Aspect. Procedia Economics and Finance, 24, 266-273. https://doi.org/10.1016/S2212-5671(15)00658-9

Halachenko, O.O. (2016). Marketynhovi instrumenty rozvytku sanatorno-kurortnykh pidpryiemstv rehionu [Marketing tools for the development of sanatorium and resort enterprises in the region]. Formation of market relations in Ukraine: Collection of scientific papers, 9(184), 133-136 [in Ukrainian].

James, P. (2015) Urban Sustainability in Theory and Practice: Circles of Sustainability. London and New York: Routledge.

Kaminska, B. (2018). Iterative signal processing in anticipatory management of industrial enterprise development. Virtual Economics, 1(1), 53-65. https://doi.org/10.34021/ve.2018.01.01(4)

Kavun, S., Caleta, D., Vrsec, M., \& Brumnik, R. (2013). Estimation of the Effectiveness and Functioning of Enterprises in Boards of Corporate Security. European Journal of Scientific Research, 104(2), 304-323 Retrieved from http://www.europeanjournalofscientificresearch.com/issues/EJSR_104_2.html.

Kunze, L. (2012). Funded social security and economic growth. Economics Letters, 115(2), 180-183. https://doi.org/10.1016/j.econlet.2011.11.032

Kurhuzenkova, L.A. (2016) Ekonomichna bezpeka pidpryiemstva: sutnist ta chynnyky formuvannia yii vidpovidnoho rivnia [Economic security of an enterprise: the essence and factors of forming its corresponding level]. Economic Bulletin of the ZDIA, 2 29-33 [in Ukrainian].

Kuzior, A., Sobotka, B., Filipenko, A., \& Kuzior, P. (2019). Marketing Communications of Administrative Organs of Loca Governance and Local Community. Marketing and Management of Innovations, 2, 314-325. http://doi.org/10.21272/mmi.2019.2-26

Kwilinski, A. (2018a). Mechanism of formation of industrial enterprise development strategy in the information economy. Virtual Economics, 1(1), 7-25. https://doi.org/10.34021/ve.2018.01.01(1)

Kwilinski, A. (2018b). Mechanism of modernization of industrial sphere of industrial enterprise in accordance with requirements of the information economy. Marketing and Management of Innovations, 4, 116-128. http://doi.org/10.21272/mmi.2018.4-11 Kwilinski, A. (2019). Implementation of Blockchain Technology in Accounting Sphere. Academy of Accounting and Financial Studies Journal, 23(SI2), 1528-2635-23-SI-2-412: 1-6.

Kwilinski, A., Volynets, R., Berdnik, I., Holovko, M., \& Berzin, P. (2019). E-Commerce: Concept and Legal Regulation in Modern Economic Conditions. Journal of Legal, Ethical and Regulatory Issues, 22(SI2), 1544-0044-22-SI-2-357: 1-6.

Lyulyov, O., Chygryn, O., and Pimonenko, T. (2018). National Brand as a Marketing Determinant of Macroeconomic Stability. Marketing and Management of Innovations, 3, 142-152. http://doi.org/10.21272/mmi.2018.3-12

Lyulyov, O., \& Shvindina, H. (2017). Stabilization Pentagon Model: application in the management at macro- and microlevels. Problems and Perspectives in Management, 15(3), 42-52.

Lyulyov, O. V., \& Pimonenko, T. V. (2017). Lotka-Volterra model as an instrument of the investment and innovative processes stability analysis. Marketing and Management of Innovations, 1, 159-169. 
Mason, C. N., Salas, D., Ebanks, J., \& Bowser K. (2013). Economic Security and Well-Being Index for Women in New York City. New York: The New York Women's Foundation.

Pakulina, A.A. (2015). Innovation development and social stability of the economic system of the region. Proceeding from: Seven International Scientific and Practical Conference «Trends and innovations in the modern economy». (pp. 240-243). Kharkiv: KhNUBA.

Pająk, K., Kaminska, B., \& Kvilinskyi, O. (2016). Modern trends of financial sector development under the virtual regionalization conditions. Financial and Credit Activity: Problems of Theory and Practice, 2(21), 204-217. https://doi.org/10.18371/fcaptp.v2i21.91052

Pajak, K., Kvilinskyi, O., Fasiecka, O., \& Miśkiewicz, R. (2017). Energy security in regional policy in Wielkopolska region of Poland. Economics and Environment, 2(61), 122-138. https://www.ekonomiaisrodowisko.pl/uploads/eis\%2061/11_pajak.pdf Reshetova, M.V., \& Krutik, A.B. (2011). Economic security: a historical approach. Scientific and Technical Statements, 5(132), 220-225.

Savchenko, T., Basiurkina, N., Rodina, O., \& Kwilinski, A. (2019). Improvement of the assessment methods of product competitiveness of the specialized poultry enterprises. Management Theory and Studies for Rural Business and Infrastructure Development, 41(1), 43-61. https://doi.org/10.15544/mts.2019.05

Tarasova, H. (2018). Scientific and methodical approach to adaptive diversification of industrial enterprise development under crisis conditions. Virtual Economics, 1(1), 42-52. https://doi.org/10.34021/ve.2018.01.01(3)

Tkachenko, V., Kwilinski, A., Klymchuk, M., \& Tkachenko, I. (2019a). The economic-mathematical development of buildings construction model optimization on the basis of digital economy. Management Systems in Production Engineering, 27(2), 119-123. http://doi.org/10.1515/mspe-2019-0020

Tkachenko, V., Kwilinski, A., Korystin, O., Svyrydiuk, N., Tkachenko, I. (2019b). Assessment of information technologies influence on financial security of economy. Journal of Security and Sustainability, 8(3), 379-390.

http://doi.org/10.9770/jssi.2019.8.3(7)

Tkachenko, V., Kwilinski, A., Tkachenko, I., \& Puzyrova, P. (2019c). Theoretical and Methodical Approaches to the Definition of Marketing Risks Management Concept at Industrial Enterprises. Marketing and Management of Innovations, 2, 228-238. http://doi.org/10.21272/mmi.2019.2-20

Tkachenko, V., Kwilinski, A., Kaminska, B., Tkachenko, I. \& Puzyrova, P. (2019d). Development and effectiveness of financial potential management of enterprises in modern conditions. Financial and Credit Activity: Problems of Theory and Practice, 3(30), 85-94. https://doi.org/10.18371/fcaptp.v3i30.179513

Vasylchak, S.V., \& Halachenko, O.O. (2016) Osnovni instrumenty vplyvu na rozvytok sanatorno-kurortnykh pidpryiemstv [The main tools of influence on the development of sanatorium and resort enterprises]. Proceeding from: Mizhnarodna naukovopraktychna Internet-konferentsiia «Problemy informatsiino-analitychnoho zabezpechennia upravlinnia ekonomichnoiu bezpekoiu pidpryiemstva, rehionu, krainy» - International Scientific and Practical Internet Conference «Problems of Information and Analytical Provision of Management of Economic Safety of the Enterprise, Region, and Country». (pp. 149-150). Poltava: Yuri Kondratyuk National Technical University of Poltava [in Ukrainian].

Vasylchak, S.V., Pushak, Ya.Ya., \& Halachenko, O.O. (2017). Rozvytok sanatorno-kurortnykh posluh rehionu yak skladova ekonomichnoi bezpeky [Development of sanatorium and resort services of the region as a component of economic security]. Turystychna osvita: yevropeiskyi vymir: zb. nauk. pr. - Tourist Education: European Dimension: Collection of Scientific Papers (pp.50-155) [in Ukrainian].

Vasyltsiv, T.H, \& Hrynkevych, S.S. (2015). Formuvannia seredovyshcha ekonomichnoi bezpeky pidpryiemnytstva v Ukrain [Formation of the environment of economic security of entrepreneurship in Ukraine]. Ekonomichnyi chasopys-XXI - Economic Magazine-XXI, 3-4(1), 24-27. [in Ukrainian].

Vasylieva, T., Lyeonov, S., Lyulyov, O., \& Kyrychenko, K. (2018). Macroeconomic Stability and Its Impact on the Economic Growth of the Country. Montenegrin Journal of Economics, 14(1), 159-170.

Wysokinska-Senkus, A., \& Raczkowski K. (2013). Economic Security in the Context of Sustainability. Rural Development. Vol. $6(1), 454-462$.

Wysokinska-Senkus, A., \& Senkus, P. (2013) Systemy zarządzania w świetle nowych wyzwan. Systemy zarządzania w świetle badan empirycznychю Rekomendacje stosowania [Management systems in the light of new challenges. Management systems in the light of empirical research. Application recommendations Application recommendations]. Warszawa: Wydawnictwo ROI. [in Polish].

Zaloznova, Yu. \& Trushkina, N. (2017). Methodical support of improving the organization of marketing activity of the coal-mining enterprises of Ukraine. Baltic Journal of Economic Studies, 3(1), 36-44. https://doi.org/10.30525/2256-0742 
A. Kwilinski, K. Pajak, O. Halachenko, S. Vasylchak, Y. Pushak \& P. Kuzior. Marketing Tools for Improving Enterprise Performance in the Context of Social and Economic Security of the State: Innovative Approaches to Assessment

O. Квілінський, Ph.D., Лондонська академія науки і бізнесу (Великобританія);

К. Пайонк, Dr.Sc., профресор, Iнститут розвитку міжнародної співпраці (Польща);

О. Галаченко, канд. мед. наук, профресор, Міжрегіональна академія управління персоналом (Україна):

С. Васильчак, д.е.н., професор, Львівський державний університет внутрішніх справ (Україна);

я. Пушак, д.е.н., профресор, Львівський державний університет внутрішніх справ (Україна);

П. Кужьор, Сілезька політехніка (Польща).

Маркетингові інструменти покращення ефективності діяльності підприємства в контексті соціальноекономічної безпеки держави: інноваційні підходи до оцінювання

Стаття узагальнює аргументи щодо наукової дискусії із вирішення проблеми покращення ефрективності діяльності підприємства в контексті соціально-економічної безпеки держави. Основною метою дослідження є проведення оцінки ефрективності діяльності підприємства і на їі основі визначення інноваційних заходів та методів, дієвих маркетингових інструментів ї покращення. Систематизація літературних джерел та наукових підходів засвідчила, що саме на основі врахування комплексної оцінки діяльності підприємства залишились ряд не вирішених проблем щодо покращення соціально-економічної безпеки держави. Актуальність вирішення даної наукової проблеми полягає в тому, що забезпечення соціально-економічної безпеки є надзвичайно важливою проблемою в теперішніх умовах розвитку країни. Методичним інструментарієм проведеного дослідження стали методи: логічного узагальнення, систематичний, порівняння, математичних розрахунків, графрічний, метод експертних оцінок. Періодом дослідження обрано 20142018 роки. Об'єктом дослідження стало санаторно-курортне підприємство, оскільки на основі діяльності саме таких підприємств на мікрорівні фоомується соціально-економічна безпека держави. Дослідження в статті визначеної проблеми здійснено в наступній логічній послідовності. Окреслено значення діяльності підприємств як складової у фоормуванні економіки країни в ринкових умовах. Відзначена важлива роль вітчизняних підприємств у забезпеченні зайнятості населення країни, формуванні суспільних відносин та підтримці соціальної стабільності, зокрема соціальноекономічної безпеки держави на мікрорівні. Виділено проблеми забезпечення економічного розвитку підприємств як складової соціально-економічної безпеки держави що потребують дослідження. Описано перелік ризиків, яким піддаються в повсякденній діяльності вітчизняні підприємства. Відзначено, що однією із складових убезпечення соціально-економічної безпеки країни на мікрорівні економічний розвиток підприємств. В контексті иього досліджено теоретичні основи формування економічної безпеки підприємств на основі оиінки ефективності діяльності на прикладі санаторнокурортних закладів. Проведена оцінка ефективності діяльності санаторно-курортних підприємств з позицій ефьективності господарюючого суб'єкта на основі розрахунку інтегрального показника та безпосередньо споживачів за допомогою експертного методу. На основі розрахунків інтегрального коефріцієнта ефрективності надання санаторно-курортних послуг за п'ять попередніх рокіе доведено нерівномірність коливання основних економічних показників діяльності підприємства, зниження коефріцієнту ефрективності фрінансово-господарської діяльності. На основі проведеного анкетування споживачів визначена середня оцінка ефрективності наданих санаторно-курортних послуг 3,7 бали, що за п'ятибальною шкалою доводить необхідність покращення діяльності санаторно-курортних закладів в умовах сьогодення та розробки спеціальних заходів із використанням дієвих інструментів стимуляиії розвитку таких підприємств. 3 метою значного підвищення ефрективності діяльності санаторно-курортних підприємств та впливу на покращення соціально-економічної безпеки в країні запропоновано сукупність дій та маркетингових інструментів на основі інноваційних технологій на рівні самих підприємств, на рівні регіону та держави. Результати проведеного дослідження можуть бути використані санаторно-курортними закладами в практичній діяльності та органами державної влади, органами місцевого самоврядування на рівні регіонів та територіальних громад при розробці проектів розвитку територій та приймання заходів по забезпеченню соціально-економічної безпеки в країні.

Ключові слова: маркетингові інструменти, інноваційні підходи, оцінка, ефективність, санаторно-курортні заклади, економічна безпека, соціально-економічної безпека, заходи.

Manuscript received: 05.08.2019.

(c) The author(s) 2019. This article is published with open access at Sumy State University. 